Joanna Targońska

Katedra Filologii Germańskiej

Uniwersytet Warminsko-Mazurski, Olsæłyn

\title{
INTERAKCJA W KLASIE JEZZYKOWEJ - METODOLOGIA BADAWCZA
}

\section{Interaction in the foreign language classroom: Research methodology}

\begin{abstract}
The present article is devoted to the discussion of the methodology of research into interaction in the foreign language classroom. It discusses selected methods which can be employed to allow a complete and reliable monitoring of the varied interactions which can occur during foreign language lessons. The paper concludes with an attempt at formulating some general principles relating to researching classroom interaction.
\end{abstract}

\section{Znaczenie pojęcia interakcja}

Interakcja, będąca centralnym pojęciem wszystkich nauk o uczeniu się i nauczaniu skierowanych na proces, jest zarówno środkiem, jak i celem procesu uczenia się/nauczania (Meißner, 2000: 161). Przy założeniu, że język jest formą działania społecznego, pojęcie interakcji i komunikacji nabierają szczególnego znaczenia na lekcji języka obcego (LJO). Język jest tu nie tylko przedmiotem nauczania, ale również środkiem służącym interakcji pedagogicznej, jak i społecznej. Nauka języka jest nie tylko procesem kognitywnym, ale też czynnością o charakterze społecznym i interakcyjnym. Chociaż proces uczenia się dokonuje się w każdym z osobna i to sam uczący się musi podjąć wysiłek uczenia się oraz zbudować własną kompetencję językowa, to proces ten niewątpliwie dokonuje się w interakcji ze środowiskiem. To właśnie ze swojego otoczenia uczący się otrzymuje dane językowe (ang. input) dostarczane mu w różnej formie, na podstawie których konstruuje swoją wiedzę językową. Również do stworzenia jak i zweryfikowania własnej hipotezy językowej, uczący się potrzebuje interakcji społecznej w formie informacji 
zwrotnej płynącej ze środowiska. Proces uczenia się bazuje więc na interakcji i konfrontacji z osobami, sytuacjami oraz materiałami dydaktycznymi.

Interakcja może być rozumiana wielorako, a najprościej ujmując można zdefiniować ją jako reakcję na reakcję (Bleyh, 2000: 33), czy jako wzajemne wpływanie na siebie pojedynczych podmiotów lub grup osób w swoich działaniach (Edmondson i House, 2000: 243). Vollmer (2000: 258) mówi zaś o wzajemnym wpływaniu na siebie co najmniej dwóch elementów, zmiennych, systemów, osób czy też kroków działania, które odnoszą się do siebie i pochodzą z różnych źródeł. Te wyżej wymienione wyjaśnienia wskazują na taki rodzaj interakcji, w której oddziaływują na siebie dwie wielkości. Vogel (2000: 251) wychodząc z założenia, iż interakcja może zachodzić jednostronnie wewnątrz podmiotu uczącego się, rozumie pod tym pojęciem: „mechanizmy sprzężenia zwrotnego, mechanizmy informacji zwrotnej oraz procesy zachodzace w systemach indywidualnych i socjalnych, ale również w maszynach, zastępujących człowieka albo zwiększających jego umiejętności” (tłum. J. T.) Jego zdaniem tylko taka definicja (w odróżnieniu od większości z nich skupiających się na płaszczyźnie komunikacyjnej, interakcyjnej, społecznej, czy też afektywnej) pozwala na uwzględnienie w pojęciu interakcji kognitywnych procesów zachodzących w uczącym się. To odmienne zrozumienie interakcji można wyjaśnić innym jej pojmowaniem w psychologii i socjologii (tu traktuje się interakcję jako działanie skierowane na daną osobę lub grupę osób) niż w badaniach nad przyswajaniem języka, gdzie centralnym elementem są takie działania symboliczne jak: komunikacja, negocjacja znaczeń prowadzące do nabywania sprawności językowych, a celem jest proces przyswajania języka obcego.

W literaturze przedmiotu wyrażane jest przekonanie, iż interakcja jest jednym z ważniejszych czynników odnoszących się do LJO. Zdaniem Scherfera (2000: 209) i Vollmera (2000) interakcja nie powinna być rozumiana jako jeden z czynników mających określone funkcje w procesie uczenia się/nauczania, bowiem nauczanie i uczenie się języka jest interakcja. Należy więc wyjść z założenia, iż każdy krok lekcyjny, każde zachowanie nauczyciela, bądź ucznia, trzeba uznać za działanie interakcyjne. $\mathrm{Na}$ jednej lekcji mamy w związku z tym do czynienia z wieloma różnymi rodzajami interakcji, które są często ze sobą związane lub się zazębiają. Pojecie interakcöi zawiera więc w sobie: czynności mymiany jezykowej, driałania zuiqzane z. nauczaniem $i$ ucz̧eniem sie jezyłka obcego (wyjaśnianie, prośba o wyjaśnienie, omawianie problemu, negocjowanie znaczenia jednostek leksykalnych, czy też negocjacja form, wypracowywanie rozwiązań, rozwiązywanie zadań) oraz inne czynniki towarzyszqce uczeniu sie $i$ nauczaniu. Moga być nimi wszystkie działania związane z lekcja, takie jak: prośba o pożyczenie ołówka, prośba o otworzenie, czy też zamknięcie okna, zakłócenie zajęć przez hałasy dochodzące z zewnątrz, ale również bodźce płynące ze strony polityki, administracji szkolnej itp. (Christ, 2000: 60-61). Także proces przekazywania wiedzy powinien być rozpatrywany jako zdarzenie interakcyjne przybierające różne formy językowe, na co niemały wpływ moga mieć stosunki panujące między nauczającym i uczącymi się (Labocha, 1996: 13). 
Interakcja może mieć charakter werbalny, bądź też niewerbalny i zdaniem Klippel (2000: 119) nie musi mieć ona charakteru intencyjnego ${ }^{1}$ oraz nie musi się dokonywać jedynie między osobami, lecz może zachodzić między jednostką a rzeczami/mediami, jak np. między tekstem a jego odbiorcą lub producentem. Z tego wynika, iż na LJO mamy do czynienia z szeregiem różnorodnych szczegółowych interakcji dających przyporządkować się określonym grupom. Klippel (2000: 119) wymienia trzy grupy interakcji zachodzących w klasie językowej: interakije interpersonalna, interakcje zachodzaca miedsy osobami a "rzeczami", oraz interakige intrapersonalna, odnosząca się do procesów zachodzacych wewnątrz podmiotu uczącego się. U Vollmera (2000: 258-259), znajdziemy również trzy grupy interakcji, różniące się jednakże od tych zaproponowanych przez Klippel (2000). Są to: interakcja miedsy uczacym sie a środowiskiem (w szerokim znaczeniu), interakcja mięsy uczacym sie a środowiskiem uczenia się, oraz interakcja intrapersonalna dokonujaca się w podmiocie uczącym się między dwoma lub większą liczbą zmiennych lub między pewnymi składowymi zmiennych.

Z przedstawionych powyżej klasyfikacji wynika, iż interakcja jest pojęciem obszernym, bardzo złożonym, co oznacza, iż jej uchwycenie również nie jest łatwą sprawą. Tym bardziej, iż jeden rodzaj interakcji może zachodzić na kilku płaszczyznach. Interakcja interpersonalna (czyli społeczna, ale również ta ze środowiskiem) dokonuje się na płaszczyźnie społecznej, afektywnej i kognitywnej, zaś dla pozostałych rodzajów interakcji charakterystyczne są płaszczyzna kognitywna i afektywna. Sama interakcja może mieć wymiar: społecznopsychologiczny, dydaktyczny, czy też komunikacyjny.

\section{Cele badań nad interakcją}

Można zadać sobie pytanie, w jakim celu przeprowadzane są badania dotyczące interakcji na LJO. Badacze zajmujący się tą tematyką wychodzą z założenia, iż jakość interakcji na lekcji ma przełożenie na jakość procesów uczenia się, nie negując jednocześnie znaczenia i wpływu czynników indywidualnych (Edmondson i House, 2000: 243) Tak więc badania nad interakcją mają na celu poznanie wpływu konkretnych czynników na zachowania interakcyjne uczniów, a tym samym znalezienie tych przyczyniających się do poprawy działania interakcyjnego uczniów w klasie językowej oraz przygotowujących ich do komunikacji poza nia. Interakcja może być jednakże, obok na przykład sprawdzania osiagnnięć w tradycyjny sposób (tj. poprzez testy, zadania), pojmowana jako jedna z form ewaluacji nauczania, bowiem analiza zachowań interakcyjnych na lekcji może

\footnotetext{
${ }^{1} \mathrm{~W}$ wypowiedziach wielu glottodydaktyków, którzy pragną rozgraniczyć pojęcia interakcja i komunikacja znajdziemy często wyjaśnienia, iż komunikacja ma charakter intencjonalny, zaś interakcja często dokonuje się nieplanowo i nie przyświeca jej jakiś konkretny cel. Komunikacja jest tylko specyficzną formą interakcji dokonująca się na płaszczyźnie werbalnej bądź niewerbalnej lub intencyjnym typem interakcji (Vollmer, 2000: 259).
} 
dać nam odpowiedź na pytanie o jakość i efektywność procesu nauczania/uczenia się (Gogolin, 2000: 97) W gronie dydaktyków znajdziemy wielu (Edmondson i House, 2000; Krumm, 2000; Solmecke, 2000), którzy są zdania, iż analiza interakcji powinna być również stosowana w kształceniu i dokształcaniu nauczycieli. Celem takich badań nie powinno być jednakże wyłącznie stwierdzenie zależności przyczynowo-skutkowej, ale przede wszystkim refleksja (w tym przyszłych) nauczycieli nad własnymi zachowaniami, jak i wypływająca z niej zmiana zachowań uczestników procesu lekcyjnego. Nauczyciele powinni być przygotowani do analizy interakcji, a jednocześnie wykształcić umiejętność samoobserwacji w odniesieniu do swojego działania jak i udzielanej informacji zwrotnej (Krumm, 2000: 135, 137). Jednocześnie przy stosowaniu w badaniach interakcji metody introspekcji lub retrospekcji można osiagnać kolejne cele, a mianowicie skłonić ucznia do refleksji nad własnym procesem uczenia się (por. Aguado, 2004; Heine, 2005), a jednocześnie uświadomić mu luki w jego kompetencjach językowych (patrz Eckert, 2002, 2003) Ponadto dzięki stosowanej w badaniach retrospekcyjnych konfrontacji ucznia z jego własna produkcją językowa połączonej z uświadomieniem mu jego niepoprawnych zachowań interakcyjnych, można przyczynić się do przyrostu jego wiedzy (House, 1996, za House, 2000: 114) i świadomości językowej.

\section{Zarys historii badań nad interakcją}

Do czasu pojawienia się pojęcia interakcji i odkrycia jej wielkiego znaczenia w procesie uczenia się/nauczania języka obcego, badania empiryczne koncentrowały się na badaniu albo nauczyciela albo ucznia. Odnosiły się więc one albo do języka nauczyciela (ich celem było uchwycenie dopasowywania wypowiedzi nauczyciela do możliwości językowych ucznia, zbadanie zadawanych przez niego pytań jak i rodzajów stosowanej korekty językowej), bądź też języka uczących się, nie łącząc tych dwóch płaszczyzn, nie badając związku między nimi. Założeniem tych prac badawczych było zazwyczaj ustalenie pewnych prototypów, czyli na przykład określenie cech typowych dla dobrych uczniów $i$ dobrych nauczycieli jezylka. Wprowadzenie pojęcia interakcji spowodowało, iż przedmiotem zainteresowania badawczego stały się te dwa podmioty i wzajemne relacje zachodzace między nimi (Vollmer, 2000: 260-261). Choć zagadnienie to dość późno znalazło swoje miejsce w dydaktyce języków obcych, to na gruncie nauk pedagogicznych interakcja była dużo wcześniej przedmiotem zainteresowania badawczego. Koncentrowano się tu na zachowaniach językowych nauczycieli w celu znalezienia optymalnego zachowania werbalnego pedagogów (Christ, 2000).

\footnotetext{
2 Ponieważ użycie języka odbywa się w interakcji, to zdaniem Henrici (1993: 216) proces uczenia się może być tylko wtedy odpowiednio zbadany, gdy podstawą i wyjściem do badań empirycznych będą rzeczywiste interakcje mające miejsce na lekcji.
} 
Pojęcie interakcji obok takich terminów jak: kompetencja interakcyjna, komunikacja i kompetencja komunikacyjna przeżywało swój rozkwit w połowie lat 70. Przeprowadzane w latach 80. i 90. badania empiryczne skupiały się w głównej mierze na opisaniu charakterystyki interakcji na lekcjach (patrz Allwright, 1988; Chaudron, 1988; Ellis, 1994, za Tönshoff, 2000: 236) Ponadto centralne miejsce zajmowały również procesy wyjaśniania, rozumienia oraz negocjacji znaczeń3 Jednakże badania koncentrujące się na zachowaniu nauczycieli lub na obserwacji interakcji nauczyciel - uczeń, zdawały się nie zauważać, iż proces nauczania/uczenia się dokonuje się w klasie językowej, w grupie posiadającej swoją dynamikę, a działania nauczyciela, będące na przykład odpowiedzią na reakcję jednego z uczniów, mogą i najczęściej uwzględniają pozostałych uczących się w klasie językowej (Krumm, 2000: 134). Tak więc interakcja nie była tu przedmiotem badań lecz stanowiła marginalną rolę. Jeżeli już stawała ona w centrum zainteresowania badawczego, wtedy najczęściej chodziło o zbadanie struktur interakcji (patrz Flanders, 1970, za Edmondson i House, 2000: 244-245), o strukturę dyskursu klasowego, konwencje i rutyny społeczne, korektę, poprawianie błędów itp. (patrz Henrici, 1990). Poza kręgiem ich zainteresowania było jednak uchwycenie pozytywnego lub negatywnego wpływu interakcji na proces przyswajania języka (Henrici, 1995, 2000).

Podwaliny pod badania nad interakcją dały m.in. takie nurty jak: socjolingwistyka i pragmatyka (podkreślające użycie języka oraz interakcje werbalne), etnometodologia ${ }^{4}$ skupiająca swoją uwagę na interakcji i konwersacji (przedmiotem jej zainteresowania była zmiana osób mówiących w rozmowie, interakcja społeczna dokonująca się w wypowiedzi), psychologia poznawcza (a zwłaszcza badania nad procesami mentalnymi wpływającymi na rozumienie tekstu), psychologia społeczna i psychologia dyskursywna ${ }^{5}$. Nie bez znaczenia była też pedagogiczna analiza interakcji, której wadami było między innymi nie uwzględnianie kontekstu interakcji oraz zbytnie koncentrowanie się na perspektywie nauczyciela (Henrici, 1990: 396).

\section{Metodologia badań nad interakcją na lekcji języka obcego}

Przystępując do omawiania metod i narzędzi badawczych, pozwalających na trafne i rzetelne uchwycenie wybranych procesów interakcyjnych zachodzących na LJO, odwołajmy się do wypowiedzi Meißnera (2000: 168) dotyczącej właśnie metodologii badań nad interakcją. Otóż uważa on, iż w odniesieniu do badania interakcji

\footnotetext{
${ }^{3}$ Przegląd takich badań niemiecko- jak i anglojęzycznych przedstawia Henrici (1990: 31).

${ }^{4}$ Etnometodologia stanowi rodzaj badań socjologicznych, a przedmiotem jej zainteresowania są kontakty socjalne (czyli reakcja uczniów na nauczyciela i odwrotnie), działanie jednostek w grupie.

${ }^{5}$ Nauka ta została zainspirowana przez psychologów społecznych w Wielkiej Brytanii, którzy chcieli uwypuklić interakcyjny aspekt rozumienia, wyjaśniania itp. (van Dijk, 2001: 37).
} 
istnieje tyle metod badawczych i tyle nastawień metodologicznych, ile jest celów badawczych. Również Henrici (2000: 107) jest zdania, iż badania te powinny mieć charakter integrujący, wielo-perspektywiczny, multi-metodologiczny, zarówno w odniesieniu do metodologii, metody zbierania materiału badawczego jak i metody jego analizy. Tak więc najważniejszym wymogiem badań nad interakcją jest stosowanie różnych metod i narzędzi badawczych, co wynika ze złożoności fenomenu, jakim jest interakcja. Nawet w jednym prostym działaniu interakcyjnym, którym może być komunikacja werbalna, mamy do czynienia z wieloma płaszczyznami oraz czynnikami mającymi ogromny wpływ na to, jak ona przebiega.

Każda interakcja ma wymiar indywidualny, a w każdym przetwarzaniu języka łączą się procesy afektywne jak i kognitywne. Interakcja komunikacyjna oparta na języku, dokonująca się w kontekście sytuacyjnym i socjokulturowym, ma nie tylko wymiar społeczny, czy też kognitywny (funkcja referencyjna języka wyrażająca się w przekazie informacji), lecz również niesie ze sobą pewne treści na płaszczyźnie afektywnej (List, 2000; Zydatiß, 2000). Tak więc w każdej z interakcji daje się zauważyć powiązanie procesów kognitywnych z emocjami. Nie można więc mówić o czysto społecznej, czy też czysto kognitywnej interakcji. Każdy rodzaj interakcji występuje na kilku płaszczyznach: społecznej, językowej, kognitywnej i afektywnej. Tak więc w badaniu zdarzenia interakcyjnego trzeba uwzględnić typowe dla każdej z interakcji płaszczyzny, a tym samym wybrać takie metody, dzięki którym możliwe będzie uchwycenie tych czynników niejako decydujących o charakterze danego rodzaju interakcji. Dlatego też ważne jest zastosowanie takich metod i narzędzi badawczych, które będą się wzajemnie uzupełniać.

\subsection{Płaszczyzny badawcze}

Niestety tylko część czynników mających wpływ na interakcję da się w ogóle zaobserwować, zaś pozostałe, niejednokrotnie ważne lub nawet decydujące, można poznać jedynie przy wielkim nakładzie pracy i zaangażowaniu ze strony badacza. Dlatego badania nad procesami interakcyjnymi zachodzacymi na lekcji języka obcego czerpią z wielu różnych metod badawczych. Po pierwsze z analizy interakcji ${ }^{6}$ (której przyświecały cele czysto dydaktyczne), z analizy dyskursu ${ }^{7}$ (mającej charakter badań etnograficznych) oraz z badań eksperymentalnych i eksploratywnych zajmujących się analizą danych językowych (które stawiały sobie za cel zbadanie związku interakcji z kognicja) (Börner, 2000: 46). Ważnym

\footnotetext{
${ }^{6}$ Analiza interakcji w ujęciu psychologicznym koncentrowała się na wzajemnym postrzeganiu siebie uczestników interakcji.

${ }^{7}$ Badania o charakterze analizy dyskursu koncentrowały się przede wszystkim na analizie zachowań werbalnych (korekta, zmiana ról) nauczyciela, jak i ucznia. Henrici (1995: 37) zwraca jednakże uwagę na fakt, iż pojęcie analizy dyskursu jest rozumiane dwojako. Z jednej strony jest ona utożsamiana $z$ analizą konwersacji. Z drugiej zaś strony analiza konwersacji jest uznawana za jedną z części analizy dyskursu.
} 
pod względem metodologicznym było włączenie do badań nad interakcją metody etnograficznej, dzięki której w badaniach stosowana jest introspekcja i retrospekcja. W literaturze glottodydaktycznej można nawet znaleźć specjalną metodę służącą badaniu interakcji, którą Henrici (1995: 149) określa jako analiza dyskursu uwrgledniajaca specyfike prayswajania jesyka (niem. fremdsprachenerwerbssperifische Diskursanalyse). Jest to taka metoda, w której analiza dyskursu jest uzupełniona badaniami introspekcyjnymi i retrospekcyjnymi, umożliwiającymi rozpoznanie problemów nie dających się zauważyć podczas analizy danych prymarnych.

Badania interakcji na lekcji skupiają się najczęściej na uchwyceniu jej na dwóch płaszczyznach. Z jednej strony koncentrują się one na płaszçyžnie spoleczno-psychologicznej (np. maja na celu uchwycenie partnerskiego zachowania w relacji nauczyciel - uczeń, lub opis interakcyjnych form socjalnych). Przedmiotem badań jest więc tutaj proces realizacji zachowań społecznych, czyli wpływanie na siebie zarówno w kierunku nauczyciel - uczeń, ale też uczeń - nauczyciel. Takie podejście badawcze wskazuje na fakt, iż LJO może być rozumiana jako następujące po sobie procesy interakcyjne, a przecież nauka języka obcego jest procesem nie tylko interakcyjnym, lecz również emocjonalnym (Vogel, 2000: 249). Z drugiej strony badania te moga mieć charakter analizy dyskursu, w których analizowane sa wypowiedzi na LJO oraz werbalne, jak i niewerbalne, reakcje partnerów komunikacyjnych na nie. Ich celem jest najczęściej znalezienie związku między interakcyjną negocjacją na lekcji, a rozwojem sprawności językowych uczących się (Vogel, 2000: 249) Badania te wychodzą z założenia, że nauka języka obcego jest procesem interakcyjnym, ale również kognitywnym. Przedmiotem zainteresowania badawczego będą więc tu dane prymarne $\mathrm{i}$ ich opis (np. reakcje językowe, intencje językowe, funkcje aktów mowy itp.).

Żadne $\mathrm{z}$ tych podejść badawczych nie jest bez wad. W pojmowaniu procesów interakcyjnych w ujęciu społeczno-psychologicznym krytykowany jest brak uwzględnienia specyfiki uczenia się języków obcych. Z kolei w badaniu interakcji w ujęciu analisy dyskursu krytyce jest poddane zawężone spojrzenie na komunikację na lekcji i większa koncentracja na komunikacji niż na procesach przyswajania języka. Wadą tych podejść jest zdaniem Vogla (2000: 250) założenie, że muszą wpływać na siebie wzajemnie dwa podmioty, dwie wielkości i że mamy tu niejako do czynienia ze schematem bodriec - reakcja. Poza kręgiem zainteresowania tych podejść badawczych są równie ważne jednostronne, niekooperacyjne połączenia komunikacyjne, a więc procesy zachodzące wewnątrz podmiotu uczącego się (interakcja intrapersonalna), jak np. porównywanie danych językowych z zasobami leksykonu mentalnego, lub z własną wiedzą o świecie, czy też wiedza językową (Vogel, 2000). Niestety gdy badania nad interakcją koncentrują się na aspekcie kognitywnym, to analiza dyskursu okazuje się być dla ich uchwycenia niewystarczająca. Procesy kognitywne włączane w proces interakcji (np. rozpoznanie reguł dotyczących języka docelowego, sprawdzenie poprawności stawianej przez siebie hipotezy) są inicjowane przez podmiot uczący się i dokonują się bez dialogu komunikacyjnego (Vogel, 2000: 250). Może właśnie dlatego 
van Dijk (2001: 27) wskazuje na potrzebę kognitywnej analizy dyskursu, która podkreślałaby konstruktywną naturę procesów mentalnych, w której ważne jest uwzględnienie kontekstu, w jakim dyskurs ma miejsce, bowiem sytuacja społeczna może wpływać na strukturę komunikatu, a cały kontekst lekcyjny niewątpliwie wpływa na zachowania interakcyjne zarówno uczniów, jak i nauczycieli. Tak więc w przypadku analizy dyskursu werbalnego, w którym produkowane dźwięki nie występuja przecież w izolacji, ważne jest uchwycenie, a następnie przedstawienie wszystkich przejawów aktywności niewerbalnej mówiącego takich jak: gestykulacja, mimika, mowa ciała itd., bowiem te zachowania stanowiace ,pozawerbalny akompaniament”, czyli nierozerwalny element aktywności werbalnej użytkownika języka, mogą odegrać potem znaczącą rolę w interpretacji dyskursu (van Dijk, 2001: 15).

W badaniach nad interakcia w odróżnieniu do analizy dyskursu kategorie badawcze nie są ustalane przed przystąpieniem do badania, lecz krystalizują się one w trakcie jego prowadzania, zaś hipotezy nie są sprawdzane pod względem poprawności, lecz są niejako generowane ${ }^{8}$ (Henrici, 2000: 107; House, 2000: 113). Tylko w ten sposób do badań jest włączana perspektywa badanych i zostaje im niejako udzielany głos, co powoduje, iż stają się oni nie tylko „przedmiotami badań", lecz stanowią ważny i znaczący podmiot badawczy w swojej subiektywności. Ponieważ interakcja nie jest jedynie procesem społecznym, czy też afektywnym, lecz również kognitywnym, dla osiąnnięcia większej rzetelności badania należy uzupełnić je badaniami typu antropologiczno-etnograficznego, do których należą introspekcja i retrospekcja. Tylko za pomoca tych metod można uchwycić to, co nie jest obserwowalne z zewnątrz, a więc dotrzeć do uświadomionych lub nie w pełni uświadomionych procesów kognitywnych (House, 2000: 113). Te wewnątrzosobowe procesy rozumienia i produkcji, inicjowane przez podmiot uczący się w celu przyswajania języka, mogą być interpretowane jako procesy kognitywne dotyczące tworzenia i testowania hipotez. Tak więc analiza społeczna procesów interakcyjnych jest jedną z możliwości (ale z pewnością nie w pełni wystarczająca) dotarcia do kognitywnych, nie dających się zaobserwować z zewnątrz, operacji dokonujących się w podmiocie uczącym się. $Z$ tego wynika, iż interpretacyjna analiza dyskursu nie jest w pełni rzetelna metodą badawczą (Vogel, 2000: 251).

W poszukiwaniu metodologii badań interakcji należy wyjść z założenia, iż dokładna analiza procesów interakcyjnych dokonujących się na LJO możliwa będzie tylko w momencie uwzględnienia w badaniach całościowej sytuacji lekcyjnej oraz odwołania się do trzech czynników: do procesów obserwowalnych, do produktów, które na niej powstaja, oraz do obserwowalnego requltatu nie obserwowalnych procesów (procesy mentalne) (Grotjahn, 1995: 457). Dobierając metody i narzędzia badawcze należy pamiętać o konieczności przedstawienia trzech perspek-

8 Henrici (2000: 107) podkreśla jednakże, iż nie można wykluczyć w tych badaniach sprawdzania prawdziwości jakiejś hipotezy. 
tyw interakcji: perspektywe podmiotów bedacych uczestnikami interak.ji (poprzez takie narzędzia badawcze jak: kwestionariusze, wywiad, wpisy w dzienniczku uczacego się, protokoły głośnego myślenia itd.) perspektywe (najlepiej neutralnego) obserwatora, ale także perspektywe całości dziatan lekcyjnych. Tylko takie ujęcie tych trzech ww. płaszczyzn i perspektyw da pełny obraz interakcji oraz pozwoli na jej holistyczne uchwycenie i efektywne zbadanie (Klippel, 2000: 122).

\subsection{Kroki badawcze - metody i narzędzia badawcze}

Ze względu na wspomnianą powyżej konieczność uchwycenia różnych czynników interakcji oraz przedstawienia interakcji z wielu perspektyw, należy w takich badaniach zaplanować kilka etapów badawczych, które zostaną przedstawione poniżej.

\subsubsection{Uchwycenie procesów obserwowalnych}

W pierwszym rzędzie badanie interakcji powinno koncentrować się na obserwacji lek.cji (wraz z następującą po niej analizą dyskursu), która będzie stanowiła empiryczne dane prymarne, będące podstawą badania interakcji. Wskazane jest nagranie obserwacji, gdyż tak uzyskane dane stanowią kompletny i zamknięty materiał badawczy, umożliwiający powrót do określonych danych w celu upewnienia się co do słuszności własnej hipotezy i interpretacji. Nagrywanie zachowań interakcyjnych z kilku kamer oraz zaangażowanie kilku obserwatorów z pewnością przyczyni się do obiektywności tychże działań badawczych (patrz Henrici, 1995: 51). Po drugie można w ten sposób uchwycić również kontekst, w którym zachodzi interakcja, a więc przedstawić całe otoczenie zachowania interakcyjnego ucznia. Danymi prymarnymi mogą być oprócz dokumentacji obserwacji (utrwalonej w zapisie cyfrowym lub w postaci transkryptu) również wszelkie produkty, które powstały na lekcji, takie jak na przykład dokumentacja w postaci ostatecznie wykonanego zadania, napisanego tekstu, przetłumaczonych zdań itp. Te wymienione dane prymarne odnoszą się jednakże jedynie do dwóch płaszczyzn: do procesów i produktów obserwowalnych oraz do dwóch perspektyw badawczych, a mianowicie perspektywy całości lekcji oraz perspektywy obserwatora. Brakuje w nich jednakże uchwycenia i przedstawienia nieobserwowalnych procesów interakcyjnych oraz perspektywy osób badanych.

\subsubsection{Uchwycenie procesów nieobserwowalnych (introspekcja, retrospekcja)}

Kolejnym krokiem w badaniu interakcji jest uzupetnienie danych prymarnych danymi sekundarmymi, które odgrywają nie tylko rolę kontrolna, lecz również wyjaśniająca wpływ różnych czynników na dany typ interakcji. Pozwalają one zarówno na uchwycenie aspektów kognitywnych i afektywnych interakcji, jak również mogą zwrócić uwagę badacza na pewne elementy, których nie rozpoznał on należycie w czasie analizy danych prymarnych lub które umknęły jego uwadze (Henrici, 
1995: 32) Jak już nadmieniono powyżej, w badaniach nad interakcją ważne jest ponadto uchwycenie procesu (a nie jedynie produktu) oraz „uczestników interakcji”". Tak więc nieodzowne jest przedstawienie perspektywy osoby działającej, czyli wykonującej konkretne działanie językowe oraz dotarcie do tych procesów wpływających w znacznym stopniu na zachowania interakcyjne badanych, których nie daje się zaobserwować, a więc uzupełnienie obserwacji poprzez introspekcje $i$ retrospekcje. Jak można scharakteryzować te metody badawcze? Nie jest to łatwe, bowiem z jednej strony wśród glottodydaktyków nie ma jednomyślności w rozumieniu pojęcia introspekcja ${ }^{9}$, a tym samym w odniesieniu do rozgraniczenia obu tych pojęć. O ile zdaniem jednych te dwa terminy stoją niejako w opozycji do siebie (różni je zasadniczo czas wykonywania badanych czynności oraz „uzewnętrznienie” własnych procesów kognitywnych przez badanych), to Aguado (2004: 26) uważa, iż pojęcie introspekcji jest pojęciem nadrzędnym dla wszystkich procedur badawczych, w których badany dokonuje samoobserwacji, zastanawia się nad swoim stanem wewnętrznym, nad procesami zachodzaccymi w nim samym oraz informuje o tym. Tak więc retrospekcja zawiera się jej zdaniem w pojęciu głównym jakim jest introspekcja ${ }^{10}$. Heine (2005: 169) jest również zdania, że retrospekcja jest szczególnym przypadkiem introspekcji.

Przykładem metody introspekcyjnej, pozwalającej na uchwycenie kognitywnego aspektu interakcji ucznia z konkretnym zadaniem językowym (odnoszącym się np. do produkcji lub recepcji tekstu), jest metoda głośnego myślenia11. Narzędzie badawcze stanowią tu protokoły głośnego mýślenia, będace dokumentacją werbalizacji aktów mentalnych dokonujących się w czasie wykonywania pewnych czynności językowych. Umożliwiają one dotarcie między innymi do kognitywnych procesów planowania, przetwarzania informacji w języku obcym, ich rekonstrukcję, a tym samym uchwycenie kognitywnych czynników wpływających na interakcję ucznia z zadaniem językowym. Zaletą introspekcji jest po-

${ }^{9} \mathrm{~W}$ najszerszym ujęciu pod pojęciem introspekecja rozumiane są wszelkiego rodzaju wypowiedzi badanego niezależnie od czasu ich wypowiadania i rodzaju przekazywanych treści. W innym ujęciu określa się tym mianem wszystkie rodzaje werbalizacji dokonywane symultanicznie względem wykonywanej czynności, w odróżnieniu do retrospekecji, która wskazuje na przesunięcie wykonywanej czynności i przesuniętą w czasie analizę własnych zachowań. Najwęższe rozumienie tego pojęcia odnosi się do symultanicznej względem wykonywania czynności werbalizacji własnych procesów mentalnych odnoszących się jedynie do płaszczyzny metakognitywnej (Heine, 2005: 166-167).W niniejszym referacie przyjmuje się drugie rozumienie tego pojęcia, które stoi niejako w opozycji do retrospekcji. Tak więc pod pojęciem introspekecja będa rozumiane wszystkie wypowiedzi badanych odnoszące się do konkretnej czynności dokonywane w momencie jej wykonywania.

10 Aguado (2004: 24) opowiadająca się za szerokim rozumieniem pojęcia introspekcji zalicza do tej metody badawczej: wywiady, ankiety, dzienniczki uczącego się, stosowaną symultanicznie do konkretnego zadania metodę głośnego myślenia, jak i uchwycenie refleksji badanego na dany temat dokonywanej po pewnym czasie.

11 Więcej na temat zalet i wad metody głośnego myślenia znajdziemy u Aguado (2004). 
stawienie podmiotu uczącego się w centrum zainteresowania badawczego, a tym samym wyjście z założenia, iż zarówno przyswajanie języka, jak i budowanie wiedzy jest procesem o charakterze indywidualnym, w którym uczący się, jako ten przetwarzający informacje, sam konstruuje swoją wiedzę i umiejętności, a wpływ na ten proces mają czynniki nie tylko kognitywne, ale również afektywne i społeczne. Badania typu etnograficznego pozwalają więc na dotarcie do czynników kognitywnych wpływających na interakcję ucznia z zadaniem językowym, a jednocześnie mogą pomóc uchwycić czynniki afektywne.

Czy dla zbadania procesów interakcyjnych dokonujących się w klasie językowej wystarczy zastosowanie badań introspekcyjnych? Niestety nie, bowiem te mają swoje wady, które można zrekompensować poprzez włączenie badań retrospekcyjnych, w których badani bezpośrednio po wykonaniu konkretnej czynności językowej, bądź dopiero po pewnym czasie, moga odnieść się do własnych procesów językowych, kognitywnych procesów przetwarzania informacji, procesu produkcji, bądź do powstałego produktu. W odróżnieniu od introspekcji, która w czasie zdobywania danych empirycznych nie steruje badanym, w badaniach retrospekcyjnych ${ }^{12}$ wypowiedzi badanych moga być sterowane poprzez konkretne bodźce (np. protokoły głośnego myślenia, nagrania video, transkrypcje), co pozwala na zajęcie się aspektami nurtującymi badacza (Heine, 2005: 170). W przypadku retrospekcyjnego badania interakcji wskazane jest stosowanie wywiadu retrospekcyjnego, w trakcie którego dokonuje się konfrontacji badanego z jego produktem (tekst, wykonane ćwiczenie, lub protokoły głośnego myślenia) lub z nagraniami video dokumentującymi proces interakcji. Jego celem jest sprowokowanie werbalizacji planów i procesów kognitywnych towarzyszących badanej interakcji, doprowadzenie do spontanicznych wspomnień badanych odnośnie badanego rodzaju interakcji, a tym samym skłonienie ich do kolejnych komentarzy, czy też wyjaśnień (Neumann, 1995: 104). Narzędziem, a jednocześnie materiałem badawczym, moga być tu również retrospekcyjne protokoły głośnego myślenia. Aguado (2004: 34) proponuje, aby wykorzystując nagrania video do elicytacji komentarzy ze strony badanych, poczatkowo pozwolić im na samodzielne zadecydowanie o tym, do jakich fragmentów chcą się oni odnieść bądź ustosunkować, a dopiero potem uzupełnić ich wyjaśnienia swoimi pytaniami (w momencie gdyby badany sam nie odniósł się do nurtujących badacza zagadnień).

Zaletą stosowania metody retrospekcyjnej (w porównaniu do introspekcji) jest możliwość uchwycenia takich procesów interakcyjnych, które w czasie badania dokonywały się zbyt szybko, ażeby badany był w stanie je zwerbalizować i poinformować o nich. W oparciu o własne doświadczenie badawcze House (m.in. 1983, 1996, za House, 2000: 113-114) stwierdza, iż retrospekcyjne odniesienie się badanych do procesów interakcyjnych okazuje się często koniecz-

\footnotetext{
12 Heine (2005: 170) podkreśla podobieństwo między sondażem a badaniem retrospekcyjnym, wskazując, iż różnica między nimi polega na tym, że w sondażu wypowiada się najczęściej na tematy ogólne, nie odnosząc się tylko i wyłącznie do jednej konkretnej czynności językowej.
} 
nym elementem korygującym subiektywne spostrzeżenia, interpretacje oraz próby wyjaśnienia przez badacza. Elementy retrospekcji moga czasami rzucić nowe światło na badane zjawiska. Reasumując można stwierdzić, iż retrospekcja pozwala na wyjaśnienie oraz uzasadnienie danego zachowania interakcyjnego badanego. Ponadto zdaniem Aguado (2004: 32) metoda retrospekcyjnego głośnego myślenia pozwala dotrzeć do wiedzy językowej, ale też do strategii stosowanych przez badanych w trakcie wykonywania danego zadania. House (2000: 114) widzi jeszcze jedną ważną zaletę włacżenia retrospekcji do badań. Otóż na podstawie własnych doświadczeń doszła ona do wniosku, iż dokonując konfrontacji uczącego się z jego działaniami interakcyjnymi, w połączeniu z oceną akceptowalności jego zachowań dyskursywnych, można doprowadzić do przyrostu wiedzy badanego. Również Aguado (2004: 35) podkreśla, że z jednej strony badania retrospekcyjne pozwalają zrekonstruować świadomość ucznia, a z drugiej zaś przyczyniają się do jej budowania.

Niestety i ta metoda badawcza nie jest bez wad, bowiem nie zawsze informacje udzielane w badaniach retrospekcyjnych są wiarygodne, ponieważ badani muszą sięgać do pamięci długotrwałej, a na podstawie wywołanych stamtąd informacji moga przedstawiać już własne hipotezy zamiast relacjonować prawdziwy przebieg badanego procesu interakcyjnego. Ale $i$ tu wady te można zredukować. Henrici (1995: 149) proponuje podwyższenie rzetelności tych badań poprzez łączenie bezpośredniego badania retrospekcyjnego, następującego tuż po zbieraniu danych prymarnych, z takim przesuniętym nieco w czasie, które ma miejsce już po wstępnej analizie podstawowych danych empirycznych.

\subsubsection{Uzupełnienie badań (analiza dokumentów, poznanie teorii subiek- tywnych itd.)}

Tam, gdzie przedmiotem zainteresowania badawczego jest człowiek, glottodydaktyka odkryła dla siebie i zaadaptowała na swoje potrzeby metode teorii subiektywnych, która zdaniem Grotjahna (1995: 457) odgrywa znaczącą rolę w wyjaśnianiu wszystkich zjawisk mających miejsce na lekcji. Teorie subiektywne, charakterystyczne nie tylko dla nauczycieli, ale również i uczących się, mogą zdaniem Meißnera (2000) mieć duży wpływ na interakcję intrapersonalną na przykład z materiałem dydaktycznym, czy też z nowym słownictwem, danymi językowymi itp. Można je co prawda poznać stosując mywiad zogniskowany, ale niestety nie wszystkie „teorie” badanych są przez nich uświadomione, dlatego też zadaniem Grotjahna (1999: 136) ważne jest ich „wydobycie” z badanego. Dla poznania tych przekonań badanych wskazane jest początkowe stosowanie częściowo wystandaryzowanych wywiadów.

Wyżej wymienione metody mogą, a często powinny, być uzupełnione metoda analiay dokumentów, a analizowanym produktem powstającym na LJO, będącym jednocześnie zwieńczeniem dokonujących się na niej procesów interakcyjnych, może być napisany przez ucznia/uczniów tekst, wykonane zadanie, spo- 
rządzona notatka itp. Innym dokumentem pozwalającym na uchwycenie procesu interakcji (aspekt kognitywny) ucznia z materiałem językowym mogą być wszelkiego rodzaju brudnopisy, notatki wraz z przekreśleniami lub wstawieniami, które uczeń może w badaniu retrospekcyjnym skomentować. Jeżeli zaś chce się uchwycić płaszczyznę emocjonalną interakcji, w takim przypadku kolejnym analizowanym dokumentem, a jednocześnie narzędziem badawczym, może być zdaniem Grotjahna (1999: 136) drienniczek uczacego sie lub wywiady narracyjne.

Większe skupienie się na kognitywnym aspekcie badania interak.ji wymaga sięgnięcia do badań nad strategiami uczenia się, ponieważ właśnie one odnoszą się do kognitywnej strony przyswajania jak i użycia języka. Ponieważ czynności interakcyjne sa ściśle związane z konkretnymi działającymi podmiotami, ważne jest $\mathrm{w}$ tych badaniach skupienie się jednocześnie na czynnikach indywidualnych tych o charakterze neurofizjologicznym (inteligencja, zdolność językowa, pamięć, lateralizacja itp.), biologicznym (płeć, wiek itd.), kognitywnym (styl poznawczy, empatia, ekstrawersja/introwersja, zależność od pola itd.), afektywnym (nastawienie, motywacja, zainteresowanie, chęć osiagnięcia sukcesu, gotowość do podejmowania ryzyka, zahamowania, strach itd.) jak i na czynnikach środowiskowych, socjokulturowych itp. (Henrici, 1995: 47, 49).

$\mathrm{Z}$ tych wyżej wymienionych względów konieczne jest stosowanie triangulacii w badaniu nad interakcją w klasie językowej (Grotjahn, 1995; House, 2000; Aguado, 2004; Heine, 2005) Lączenie metod, narzędzi badawczych, czy nawet triangulacja badaczy (patrz Grotjahn, 1995: 460) pozwoli nie tylko na skompensowanie słabych stron każdej z metod i narzędzi badawczych, ale umożliwi również dogłębniejszy wgląd w przedmiot badania. Zdaniem Aguado (2004: 25) pozwala ona na "przełamanie hierarchii" oraz prowadzi do poszerzenia perspektywy badawczej. Tylko dzięki łączeniu metod badawczych można uchwycić perspektywę badacza, perspektywę całej lekcji z jej fazami, perspektywę grupy uczących się jak i perspektywę pojedynczych podmiotów uczących się.

\section{Podsumowanie - zasady badań nad interakcją}

Jak już wyżej pokazano, metodologia badań nad interakcją opiera się na triangulacji, a więc łączeniu ze sobą różnych metod i narzędzi badawczych. Ważne jest więc $w$ nich odwołanie się do metody obserwacji, metod etnograficznych (introspekcja, retrospekcja) oraz wykorzystanie powstałych na lekcji dokumentów. Chociaż interakcja jest przedmiotem zainteresowania badawczego wielu nauk stosujących różnorodne metody badawcze, można pokusić się tu o sformułowanie podstawowych zasad przeprowadzania badań nad interakcją w klasie językowej. Tak więc przy badaniach zdarzeń interakcyjnych należy pamiętać o wymienionych poniżej zasadach:

1. Ponieważ interakcja jest $\mathrm{w}$ głównej mierze działaniem społecznym, ważne jest przeprowadzenie takich badan nad interakcja w rzeccyymistej sytu- 
acji lekecyjnej, a więc w sytuacjach poniekąd naturalnych dla dyskursu edukacyjnego (Klippel, 2000: 122).

2. Zebrane dane służą niejako generowaniu nowej hipotezy, a nie jej sprawdzeniu, a poza tym lepiej nadają się do uchwycenia indywidualnego charakteru interakcji (Henrici, 1995: 50). Ważne jest także, aby zebrane dane nie byly $w$ żaden sposób poprawiane, lecz poddawane analizie w swojej autentycznej postaci (Van Dijk, 2001: 40).

3. W badaniu interakcji w klasie językowej wskazane jest holistyczne podejście do badania (Klippel, 2000: 124). Oznacza to, że nie można badać jej w izolacji od czynników zarówno zewnętrznych jaki i wewnętrznych. Konieczne jest więc odwołanie się do procesów obserwowalnych, nieobserwowalnych, jak i do powstających na lekcji produktów oraz przedstawienie wszystkich perspektyw danej interakcji: perspektywę badacza, badanych i całości lekcji.

4. Z pojęciem interakcji ściśle związany jest kontekst (komunikacja dokonuje się zawsze w jakimś kontekście), bowiem wskazówki nauczyciela dotyczące działań lekcyjnych, jak i wypowiedzi uczniowskie pojawiają się w konkretnym kontekście i mają one charakter sytuacyjny (van Dijk, 2001: 40), dlatego badania nad interakcją zawsze muszą go uwzględniać (patrz Krumm, 1984: 85; Gogolin, 2000: 98)

5. Gdy interakcja staje się przedmiotem zainteresowania badawczego, wskazane jest ograniczenie badania do określonego typu interakcji. Ważne jest jednakże uchwycenie wszystkich jej aspektów: społecznego, językowego, afektywnego i kognitywnego oraz czynników mających znaczący wpływ na przebieg i charakter danego rodzaju interakcji.

6. Konieczne jest przeanalizowanie, jakimi danymi sekundarnymi należy uzupełnić dane prymarne (aby ocena zaobserwowanych zjawisk była bardziej rzetelna), oraz jaki dobór narzędzi badawczych pozwoli nie tylko na dogłębniejszą analizę procesów interakcyjnych, ale również na przedstawienie danych jako procesu (Henrici, 1995: 21-22). Przed przystapieniem do analizy danych prymarnych wskazana jest faza, w której badacz zapozna się z transkrybowanymi danymi, co pozwoli mu na wynotowanie elementów, którym należałoby poświęcić nieco więcej uwagi. W tej fazie można już formułować pewne założenia, przypuszczenia, które powinny być sprawdzone w toku dalszych badań (Henrici, 1995: 39).

7. Ponieważ jednym z czynników wpływających na interakcję w klasie językowej jest konkretna faza lekcji, to interpretacja zachowań interakcyjnych z pewnością musi być związana z interpretacja okereślonej fazy lek.cyjnej (Edmondson i House, 2000: 262).

8. Nie można równiė̇ zapominać, iż dyskurs, czy tė̇ interakcja maja budowe sekwencyjna, co oznacza, że pewne zachowania werbalne lub niewerbalne powinny być opisywane i interpretowane w odniesieniu do poprzedza- 
jących je elementów komunikacji, bowiem te mogą mieć wpływ na przebieg dyskursu klasowego.

9. Ponieważ uczestnicy dyskursu stosują pewne strategie kognitywne, jak i interakcyjne, ważne jest ich uchwycenie w tychże badaniach, a więc odwołanie się do umysłów uczestników interakcji i uchwycenie ich przeżyć (van Dijk, 2001: 42).

Chociaż badanie interakcji nie jest łatwym przedsięwzięciem, to z pewnościa podjęcie takich badań może przyczynić się do rozpoznania czynników wpływających pozytywnie, jak i negatywnie na zachowania interakcyjne uczestników procesu edukacyjnego. Poznając te czynniki nauczyciel może tak pokierować dyskursem edukacyjnym, aby ułatwić uczniom nie tylko przyswajanie języka, ale również wyposażyć ich w umiejętność wchodzenia w interakcję na różnych płaszczyznach.

\section{BIBLIOGRAFIA}

Allwright, R. L. 1988. Observation in the language classroom. London: Longman. Aguado, K. 2004. „Introspektive Verfahren in der empirischen Fremdsprachenerwerbsforschung. Methodisch-methodologische Überlegungen". [w:] Fremdsprachen und Hochschule 71: 24-38.

Bleyhl, W. 2000. „Interaktion, die soziale Komponente im bio-psycho-sozialen Geschehen des Spracherwerbs". [w:] Bausch, K. R., Christ, H., Königs, F. G. i Krumm, H. J. (red.). Interaktion im Kontext des Lebrens und Lernens fremder Sprachen. Tübingen: Narr. 33-44.

Börner, W. 2000. „Interaktion in Lernaufgaben”, w: Bausch, K. R., Christ, H., Königs, F. G i Krumm, H. J. (red.). Interaktion im Kontext des Lehrens und Lernens fremder Sprachen. Tübingen: Narr. 45-50.

Chaudron, C. 1988. Second language classrooms. Research on teaching and learning. Cambridge: Cambridge University Press.

Christ, H. 2000. „Die Dimension 'Interaktion' bei der Erforschung des Lehrens und Lernens fremder Sprachen". [w:] Bausch, K. R., Christ, H., Königs, F. G. i Krumm, H. J. (red.). Interaktion im Kontext des Lehrens und Lernens fremder Sprachen. Tübingen: Narr. 59-67.

Van Dijk, T. A. 2001. „Badania nad dyskursem”. [w:] van Dijk, T. (red.). Dyskurs jako struktura i jako proces. Warszawa: Wydawnictwo Naukowe PWN. 9-44.

Eckerth, J. 2002. „Aushandlung und Erwerb von L2-Strukturen in aufgabenbasierten Interaktionen". [w:] Börner, W. i Vogel, K. (red.). Grammatik und Fremdsprachenerwerb. Kognitive, psycholinguistische und erwerbstheoretische Perspektiven. Tübingen: Narr. 165-185.

Eckerth, J. 2003. „Lemer-Lerner-Interaktion im Fremdsprachenunterricht: Fehlerquelle oder Lerngelegenheit". [w:] Fremdsprachen Lehren und Lernen 32: 214-229.

Ellis, R. 1994. The study of second language acquisition. Oxford: Oxford University Press. 
Edmondson, W i House, J. 2000. Einführung in die Sprachlehrforschung. (wydanie drugie). Tübingen, Basel: Francke.

Flanders, N. A. 1970. Analysing teacher behavior. Reading, MA: Addison-Wesley.

Gogolin, I. 2000. „Interaktion”. [w:] Bausch, K. R., Christ, H., Königs, F. G. i Krumm, H. J. (red.). Interaktion im Kontext des Lehrens und Lernens fremder Sprachen. Tübingen: Narr. 97-103.

Grotjahn, R. 1995. „Empirische Forschungsmethoden: Überblick”. [w:] Bausch, K. R., Christ, H., Krumm, H. J. (red.). Handbuch Fremdsprachenunterricht. Tübingen, Basel: Narr. 457-461.

Grotjahn, R. 1999. „Thesen zur empirischen Forschungsmethodologie”. [w:] Zeitschrift für Fremdsprachenforschung 10: 133-158.

Heine, L. 2005. „Lautes Denken als Forschungsinstrument in der Fremdsprachenforschung". [w:] Zeitschrift für Fremdsprachenforschung 16: 163-185.

Henrici, G. 1990. „'L2 Classroom Research’: Die Erforschung des gesteuerten Fremdsprachenerwerbs". [w:] Zeitschrift für Fremdsprachenforschung 1: 21-61.

Henrici, G. 1993. „Fremdsprachenerwerb durch Interaktion? Zur Diskussion und Überprüfung einer Hypothese aus der Forschung zum gesteuerten Zweitsprachenerwerb". [w:] Fremdsprachen Lehren und Lernen 22. 215-237.

Henrici, G. 1995. Spracherwerb durch Interaktion? Eine Einfübrung in die fremdsprachenerwerbsspezifische Diskursanalyse. Baltmannsweiler: Schneider Verlag Hohengehren.

Henrici, G. 2000. „Wer (Fremd)sprachenerwerb sagt, muss auch Interaktion sagen. Anmerkungen zu einer zentralen Kategorie bei der Erforschung des Fremdsprachenerwerbs”. [w:] Bausch, K. R., Christ, H., Königs, F. G. i Krumm, H. J. (red.). Interaktion im Kontext des Lehrens und Lernens fremder Sprachen. Tübingen: Narr. 104-110.

House, J. 1983. „Learning to talk. Talking to learn. Eine Untersuchung des Lernerverhaltens in zwei verschiedenen Diskurstypen”. [w:] Heid, M. (red.). New Yorker Werkstattgespräch 1982. München: Goethe Institut. 158-179.

House, J. 1996. „Developing pragmatic fluency in English as a foreign language: routines and metapragmatic awareness". [w:] Studies in Second Language Acquisition 18: 225-252.

House, J. 2000. „Interaktion im Fremdsprachenunterricht”. [w:] Bausch, K. R., Christ, H., Königs, F. G. i Krumm, H. J. (red.). Interaktion im Kontext des Lehrens und Lernens fremder Sprachen. Tübingen: Narr. 111-118.

Klippel, F. 2000. „Zur pädagogischen Interaktion im Fremdsprachenunterricht”. [w:] Bausch, K. R., Christ, H., Königs, F. G. i Krumm, H. J. (red.). Interaktion im Kontext des Lehrens und Lernens fremder Sprachen. Tübingen: Narr. 119-125.

Krumm, H. J. 1984. „Probleme des empirischen Vorgehens bei der Erforschung des Fremdsprachenunterrichts" [w:] Bausch, K. R., Christ, H., Hüllen, W. Krumm, H. J. (red.). Empirie und Fremdsprachenunterricht. Tübingen: Narr. 83-90.

Krumm, H. J. 2000. „Pädagogische Interaktion im Fremdsprachenunterricht Fremdsprachenunterricht als Interaktion”. [w:] Bausch, K. R., Christ, H., 
Königs, F. G. i Krumm, H. J. (red.). Interaktion im Kontext des Lebrens und Lernens fremder Sprachen. Tübingen: Narr. 132-138.

Labocha, J. 1996. „Dyskurs jako proces przekazywania wiedzy”. [w:] Rittel, T. (red.). Dyskurs edukacyjny. Kraków: Wydawnictwo Naukowe Wyższej Szkoły Pedagogicznej w Krakowie. 9-15.

List, G. 2000. „Zur Rolle der Emotion und Akkommodation in der Interaktion”. [w:] Bausch, K. R., Christ, H., Königs, F. G. i Krumm, H. J. (red.). Interaktion im Kontext des Lebrens und Lernens fremder Sprachen. Tübingen: Narr. 154-160.

Meißner, F. J. 2000. „Interaktion - als Gegenstand unterrichtlicher Kommunikation und prozessorientierter Forschung". [w:] Bausch, K. R., Christ, H., Königs, F. G. i Krumm, H. J. (red.). Interaktion im Kontext des Lehrens und Lernens fremder Sprachen. Tübingen: Narr. 161-170.

Neumann, G. 1995. „Laut Denken und Still Schreiben. Zur Triangulierung von Prozeß- und Produktdaten in der L2-Schreibprozeßforschung". [w:] Zeitschrift für Fremdsprachenforschung 6: 95-107.

Scherfer, P. 2000. „Interaktion und Fremdsprachenlernen in Begegnungssituationen”. [w:] Bausch, K. R., Christ, H., Königs, F. G. i Krumm, H. J. (red.). Interaktion im Kontext des Lebrens und Lernens fremder Sprachen. Tübingen: Narr. 209-217.

Solmecke, G. 2000. „Beobachtung und Analyse der Lehreräußerungen als Steuerungsinstrument”. [w:] Bausch, K. R., Christ, H., Königs, F. G. i Krumm, H. J. (red.). Interaktion im Kontext des Lehrens und Lernens fremder Sprachen. Tübingen: Narr. 227-233.

Tönshoff, W. 2000. „Zur Funktion des Faktors 'Interaktion' im Fremdsprachenunterricht”. [w:] Bausch, K. R., Christ, H., Königs, F. G. i Krumm, H. J. (red.). Interaktion im Kontext des Lebrens und Lernens fremder Sprachen. Tübingen: Narr. 234-240.

Vogel, K. 2000. „Interaktion in der Lernersprache”. [w:] Bausch, K. R., Christ, H., Königs, F. G. i Krumm, H. J. (red.). Interaktion im Kontext des Lehrens und Lernens fremder Sprachen. Tübingen: Narr. 249-257.

Vollmer, H. 2000. „Zweitspracherwerb ist Interaktion”. [w:] Bausch, K. R., Christ, H., Königs, F. G. i Krumm, H. J. (red.). Interaktion im Kontext des Lehrens und Lernens fremder Sprachen. Tübingen: Narr. 258-270.

Zydatiß, W. 2000. „Interaktive Gesprächskompetenz: ein realistisches Ziel oder ein 'trivialer' Gegenstand des Fremdsprachenunterrichts?”. [w:] Bausch, K. R., Christ, H., Königs, F. G. i Krumm, H. J. (red.). Interaktion im Kontext des Lebrens und Lernens fremder Sprachen. Tübingen: Narr. 271-279. 